Author: A Saurombe

The Southern African Development Community trade legal instruments compliance with certain criteria of GATT Article XXIV

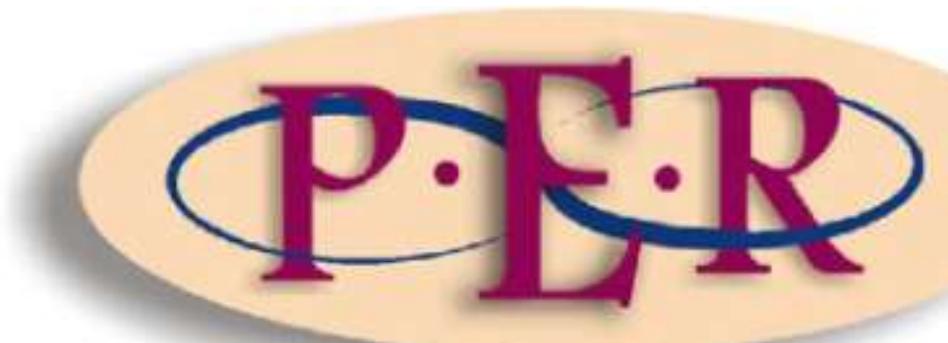

2011 VOLUME 14 No 4

http://dx.doi.org/10.4314/peli.v14i4.10 


\section{The Southern African Development Community trade legal instruments compliance with certain criteria of GATT Article XXIV*}

A SAUROMBE**

\section{List of abbreviations and acronyms}

ACP - African, Caribbean and Pacific Group of States

BLNS- Botswana, Lesotho, Namibia and Swaziland

CRTA- Committee on Regional Trade Agreements

CTG- Council on Trade in Goods

EPA- Economic Partnership Agreements

EU- European Union

FTA- Free Trade Area

GATS- General Agreement on Trade in Services

GATT- General Agreement on Tariffs and Trade

MFN- Most favoured Nation

ORC- Other Regulations of Commerce

RTA- Regional Trade Agreement

SADC- Southern African Development Community

SAT- Substantially All Trade

WTO- World Trade Organisation

\section{Introduction}

Since the inception of the GATT and now the World Trade Organisation (WTO) ${ }^{1}$, Member countries have been allowed to conclude customs unions and free trade areas. (FTAs) ${ }^{2}$ as an exception to the fundamental principle of non-discrimination set

* This paper is derived from a thesis submitted in fulfilment of LLD studies

** A Saurombe. LLB (Fort Hare), LLM (UWC, Amsterdam Law School). LLD candidate, North West University (Potchefstroom) Senior Lecturer, Mercantile Law Department, University of South Africa (sauroa@unisa.ac.za).

1 Hereafter "WTO".

2 Hereafter "FTA". Article XXIV:8 stipulates the requirement for customs union and free-trade area as follows: For the purposes of this Agreement: (a) A customs union shall be understood to mean the substitution of a single customs territory for two or more customs territories, so that (i) duties and other restrictive regulations of commerce (except, where necessary, those permitted under Articles XI, XII, XIII, XIV, XV and XX) are eliminated with respect to substantially all the trade between the constituent territories of the union or at least with respect to substantially all the trade 
out in the most favoured nation provision of Article 1(MFN). ${ }^{3}$ During the Uruguay Round, Article XXIV was clarified to some extent and updated by an understanding on its interpretation. ${ }^{4}$ The Southern African Development Community $(S A D C)^{5}$ is a Regional Trade Agreement (RTA) ${ }^{6}$ established under GATT Article XXIV. ${ }^{7}$ The historical underlying scheme behind the provisions in Article XXIV was that the GATT would as a rule allow formation of an RTA but only as a reward for fully fledged liberalisation in the form of either a customs union or an FTA among the constituent members. ${ }^{8}$ This paper seeks to investigate and evaluate SADC's compliance with GATT Article XXIV provisions. Since the legal regime for trade in services is still in its infancy in SADC, the focus of this discussion is restricted to trade in goods. The exercise of determining SADC's compliance with Article XXIV will prove difficult and may not produce conclusive results since Article XXIV itself is clouded in controversy. The GATT Treaty's loopholes for FTAs in Article XXIV has puzzled and deceived prominent scholars. ${ }^{9}$ It has been criticised for being extremely elastic. ${ }^{10}$ This means that it can be stretched to undesirable limits. It is also 'unusually complex' and is branded 'a failure, if not a fiasco'.11 It is difficult to understand and its application also produces complex results. The meaning also

in products originating in such territories, and, (ii) subject to the provisions of paragraph 9 , substantially the same duties and other regulations of commerce are applied by each of the members of the union to the trade of territories not included in the union; (b) A free-trade area shall be understood to mean a group of two or more customs territories in which the duties and other restrictive regulations of commerce (except, where necessary, those permitted under Articles XI, XII, XIII, XIV, XV and XX) are eliminated on substantially all the trade between the constituent territories in products originating in such territories.

Hereafter referred to as "MFN". Under the MFN Principle WTO members cannot normally discriminate between their trading partners. If one member grants to another a special favour (such as a lower customs duty rate for one of their products) that member has to do the same for all other WTO members.

4 See Doha Ministerial Meeting 2001: Briefing notes WTO Website http://www.wto.org/english/thewto_e/minist_e/min01_e/brief_e/brief20_e.htm accessed 20 May 2011. The interpretation's main principle is that the purpose of an RTA should be to facilitate trade between the constituent countries and not to raise barriers to the trade of other WTO members not parties to the RTA. This understanding has made it clear that a question as to whether Article XXIV is being followed by any member when it forms a Preferential Trade Area (SADC is one) can be brought before the Dispute Settlement Body. This clarification is vital as the examination of PTAs by contracting parties during the GATT years could not yield any noticeable result in ensuring their consistency with GATT rules.

Hereafter "SADC".

Hereafter "RTA".

Article XXIV: 7(a).

Park 'Regionalism, Open Regionalism'. 263

Chase 'Multilateralism compromised' 1-30.

Curzon Multilateral Commercial Diplomacy 367.

Dam The GATT: Law and International Economic Organisation 392 
gets lost in this complexity. Bhagwati ${ }^{12}$ describes it as 'full of holes'. Its language is full of 'ambiguities' and 'vague phrases', adding that it is an 'absurdity' and a 'contradiction'. ${ }^{13}$ Notwithstanding these criticisms levelled against Article XXIV, this paper will attempt to establish SADC's compliance with selected GATT Article XXIV provisions. This is of critical importance since Article XXIV remains the most effective tool in regulating the growing contentious relationship between regionalism that manifests itself in FTAs and customs unions vis-a-vis the multilateral trading system as championed by the WTO.

\section{Background}

\subsection{Regionalism vs. Multilateralism}

The question of whether RTAs have functioned as 'building blocks or 'stumbling blocks' in the multilateral process has been subjected of too much debate in recent years. Those believing in the negative effects of the regionalism drive point out its potential to fragment multilateralism. The argument is that when these blocks expand, their market power and influence is widespread, providing an incentive to use trade policy to restrict imports. This argument identifies customs unions and FTAs as the potential trade blocks that can cause this adverse effect. However, there is no evidence to date that suggest RTAs have pursued this incentive to raise external barriers. The sudden increase of RTAs has also led to the establishment of parallel and overlapping dispute settlement forums between the RTAs and the WTO. RTAs have the potential to build up jurisprudence conflicting with that of the WTO.

However the existence of a relationship between regionalism and multilateralism is very important for global trade governance. It can be argued that RTAs, by moving at a faster pace than WTO rules while sharing the WTO's goals, strengthens the latter. It also has to be realised that RTAs, being small in nature, can be more effective in tackling new areas such as services, investment, intellectual property protection, cooperation in competition policy, technical standards and government procurement than multilateral rule-making. These so called new generation issues are the core issues deadlocking the Doha Development Agenda.

Bhagwati Regionalism and Multilateralism 22.

Haight 'Customs Unions and Free Trade Areas'. 1-35 


\subsection{Importance of WTO rules for regional integration}

From the outset it is worth noting that in international law there is no hierarchy among treaties, except for the supremacy of the Charter of the United Nations over any other international agreement, as expressly provided for in Article 103 of the Charter. ${ }^{14}$ Given this basis, one may argue that in the event of conflict between any rules of the WTO and the RTA, there is no clear-cut hierarchy among them since both belong to the same category of international treaties. Accordingly, their relationship would be determined in the light of Article 30 of the Vienna Convention. However, the fallacy in the approach of resorting to Article 30 and equating similar status to RTAs and WTO rules would be evident if we take into account the provisions of Article 41(1) of the Vienna Convention. As Article XXIV of the GATT allows the execution of international treaties in the form of customs unions and FTAs, by virtue of Article 41(1) of the Vienna Convention, the latter kind of treaties could modify the provisions of the former only if it is allowed by the former. ${ }^{15}$ Therefore the argument is tenable that Article 41(1) implies that the WTO rules are inherently of a higher rank than RTAs. ${ }^{16}$ What this means is that RTAs are subservient to the rules of the WTO in the same manner as ordinary legislation of parliament in a domestic legal context would be to provisions of the constitution. ${ }^{17}$ The fact that this debate exists highlights how important it is that WTO rules governing the establishment of RTAs should neutralise their adverse systemic effects on the multilateral trading system. Article XXIV has opened the space where RTAs could blossom and enter into competition with the multilateral system. The focus will now be directed on a number of rules by which RTAs have to abide before WTO approval for such arrangements is granted. At the same time an analysis of some of the controversies around these rules is undertaken.

\section{Selected criteria to be met by SADC and other RTAs in a similar position}

The selected prescribed criteria of Art XXIV to be discussed include the notification requirement, the neutrality of trade restrictiveness requirement, the substantially all

\footnotetext{
14 See Article 103 of the Charter of the United Nations and Article 30 of the Vienna Convention on the Law of Treaties.

Cottier and Foltea 'Constitutional Functions of the WTO and Regional Trade Agreements' 43. Ibid lbid
} 
trade requirement, and the prescribed transitional period. These will be discussed in detail below.

\subsection{The Notification requirement}

All RTAs concluded by WTO Member countries require notification. Those RTAs involving developing countries like SADC have the option to be notified under the Enabling Clause while those involving developed countries are sent to the Committee on Regional Trade Agreements (CRTA) ${ }^{18}$ for examination. Some WTO Members argue that the Enabling Clause is not appropriate to deal with RTAs which take the form of either a customs union or an FTA which should be covered by Article XXIV. According to this view, the Enabling Clause should be confined to preferential trade agreements which stop short of an FTA or customs union.

Article XXIV paragraph 7 sets the obligation for parties to an RTA to notify other members and to make available to them;

such information regarding the proposed union or area as will enable them to make such reports and recommendations to contracting parties ${ }^{19}$

\subsubsection{The Transparency Mechanism ${ }^{20}$}

On 14 December 2006, the WTO General Council established on a provisional basis a new transparency mechanism for all RTAs. The new transparency mechanism negotiated in the Negotiating Group on Rules provides for early announcement of any RTA and notification to the WTO. ${ }^{21}$ The Transparency Mechanism clarifies and

18 The CRTA's terms of reference can be found in WT/L/127. Available on: http://www.wto.org/english/tratop_e/region_e/regcom_e.htm.

Accessed 06/06/2011 The WTO General Council established the Committee on Regional Trade Agreements in 1996. Its two principal duties are to examine individual regional agreements and to consider the systemic implications of the agreements for the multilateral trading system and the relationship between them. The Protocol is supposed to be subjected to the criteria set out by the CRTA of 1996. Furthermore the Transparency Mechanism of 2006 is based on the two principle duties of CRTA OF 2006; hence the SADC Protocol on Trade of 2000 is subjected to the transparency criteria.

19 Article XXIV, paragraph 7 (a)

20 For the latest version of the Transparency Mechanism as approved by the WTO General Council Decision December 2010 WT/L/806

21 Hoekman and Mavroidis 'WTO Dispute Settlement, Transparency and Surveillance' 1. 
strengthens the notification obligations of WTO Members and introduces new procedures to enhance the transparency of RTAs. ${ }^{22}$ There was widespread acknowledgement among Members that the existing RTAs surveillance mechanism was largely ineffective. ${ }^{23}$ Evidence show that over the CRTAs five years of existence the quality of the Standard Formats and statistics information provided by members had varied considerably. Some members had provided detailed statistics at the tariff line level to support the examination process, but others had expressed themselves unable or unwilling to do so. ${ }^{24}$

Under the New Transparency Mechanism members will consider the notified RTAs on the basis of a factual presentation by the WTO Secretariat. The CRTA will consider RTAs falling under Article XXIV of GATT and Article V of the General Agreement on Trade in Services (GATS). The Committee on Trade and Development will consider RTAs falling under the Enabling Clause (trade arrangements between developing countries). The transparency mechanism is implemented on a provisional basis and is to be replaced by a permanent mechanism to be adopted as part of the Doha Round of Trade Negotiations. ${ }^{25}$ Members are to review, and if necessary modify, the decision, and replace it by a permanent mechanism adopted as part of the overall results of the Doha Round.

Upon notification, and without affecting members' rights and obligations under the WTO agreements under which it has been notified, the RTA shall be considered by Members under the procedures established in paragraphs 6 to 13 of the Transparency Mechanism for RTAs.

According to the Transparency Mechanism member parties to a newly signed RTA shall convey to the WTO, in so far as and when it is publicly available, information on the RTA, including its official name, scope and date of signature, any foreseen timetable for its entry into force or provisional application, relevant contact points

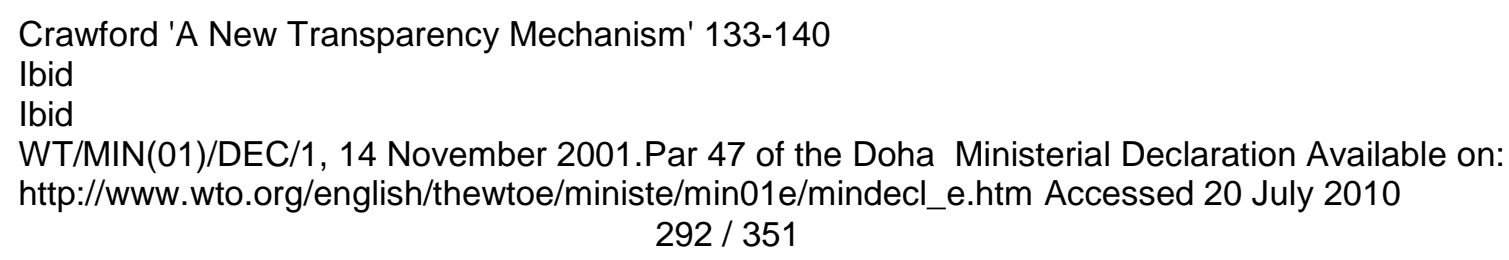


and/or website addresses and any other unrestricted information. ${ }^{26}$ Upon receipt of this information the WTO Secretariat will post it on the WTO website and will periodically provide members with a synopsis of the communications received. This requirement is important because it promotes transparency and fairness in global trade. ${ }^{27}$ This purpose is highlighted here;

Upon receiving information concerning the RTAs, other WTO members are entitled to make recommendations, which the RTA parties should be ready to abide to. ${ }^{28}$

The need for notification of a FTA, customs union or interim agreement to the WTO is clearly stated and emphasised. ${ }^{29}$ The required notification of an RTA by members that are party to it shall take place as early as possible. As a rule, it will occur no later than directly following the parties' ratification of the RTA or any party's decision on application of the relevant parts of an agreement, and before the application of preferential treatment between the parties. The weakness of this provision is that no adequate guidance is given as to when notification should be made to the WTO. It has been customary since the 1950s for WTO members to notify the WTO after the RTA they formed has been adopted in Member States legislative system. This procedure is logical given that it removes the risk of the regional arrangement being rejected by domestic legislatures after it has obtained the approval of the WTO. However, notification of an RTA does not equate with approval.

The WTO Council is against this practice ${ }^{30}$ It insists that prompt notification requires that Member States of the regional organisation promptly notify the WTO of the arrangement after it has been signed by all contracting parties. This has to be done so that such an arrangement can be on the agenda of the Council's first meeting after the signing of the regional arrangement; however, RTAs appear on the

26 WTO WT/L/671 16 Dec 2006. This forms part of the feature of 'early announcement'. There is no obligation in Article XXIV to announce agreements early.

27 A list of notified RTAs is available on: http://www.wto.org/english/tratop_e/region_e/status_e.xls accessed 20 May 2011.

28 Article XXIV, paragraph 7 (b) This is the case only for agreements which are notified to the WTO as 'interim agreements'. In practice, WTO members do not notify their RTAs of interim agreements.

29 Article XXIV of GATT, paragraphs 7 and 23 of the Transparency Merchanism. In notifying their RTA, the parties shall specify under which provision(s) of the WTO agreement it is notified. They will also provide the full text of the RTA and any related schedules, annexes and protocols, in one of the WTO official languages; if available, these shall also be submitted in an electronically exploitable format. Reference to related official Internet links shall also be supplied. 
Council's agenda for information purposes only. The Council's position is meant to encourage Member States to enter into arrangements which provide a shorter time period between the signing of the agreement and its coming into force. ${ }^{31}$

\subsubsection{Compliance with notification in SADC}

On 2 August 2004, SADC notified the Protocol on Trade in the Southern African Development Community and the Amending Agreement to the Protocol to the WTO under Article XXIV:7(a) of the GATT 1994, as aiming at establishing a free trade area. $^{32}$ SADC would have also qualified to notify under Paragraph 4 (b) of the Enabling Clause since the RTA involves developing countries. The terms of reference for the examination of the Protocol were adopted by the Council for Trade in Goods on 1 October 2004..$^{33}$ The text of the Protocol and the Amendment Protocol were circulated to WTO Members as documents WT/REG176/1 and WT/REG176/2/Rev. $1^{34}$ The SADC Trade Protocol entered into force in the year 2000; hence the notification date of 2004 means notification was not strictly complied with. $^{35}$

Reasons for the delayed notification could be that some SADC Members were unhappy that the Protocol on trade provides no favourable solution to the problems faced by the region. They were afraid of industrial polarisation and trade diversion. Despite these suggested reasons notification is a requirement that has to be fulfilled 'as early as possible'... no later than directly following the parties ratification of the RTA or any party's decision on application of the relevant parts of an agreement, and 'before' the application of preferential treatment between the parties. In practice this means that WTO Members have to be informed before the implementation of the RTA.

$31 \quad$ Kumar 'Article XXIV' 4

32 (WT/REG176/N/1/Rev.1) The delegation from the Tanzanian Mission presided over the notification.

33 WT/REG176/3 Protocol on Trade in the Southern African Development Community. Notification from Tanzania (WT/REG176/N/1 and Rev.1, WT/REG176/1, WT/REG176/2).

34 Available, together with their Annexes, on the SADC Official website (http://www.sadc.int)

35 See note 14 above for clarity. The purpose of notification is also to allow other WTO members to be informed about the creation of an RTA that may impact on their trade relations with the members of such an RTA; for example the effects of trade diversion whereby efficient export suppliers outside the customs union are replaced by inefficient suppliers within the customs union. The period of 4 years between the signing of the protocol and its notification defeats the purpose of such notification. 
Prompt notification of subsequent changes in the SADC RTA has not been done; hence in practical terms SADC is in violation of the notification requirement because some years have passed without notification of the proposed customs union. ${ }^{36}$ This is not just unique to SADC. The obligation for notification has not been complied with in a systematic manner by WTO Members and Crawford $^{37}$ notes that;

While the wording of GATT Article XXIV suggests that an RTA should be notified before the entry into force of the RTA, notifications are generally received after entry into force, in some cases months or even years after.

\subsection{Article XXIV: 5(a) Neutrality of trade restrictiveness requirement.}

This Article refers to customs unions. According to it, the 'duties and other regulations of commerce' imposed at the institutions of any such union...in respect of trade with contracting parties not parties to such union or arrangement shall not on the whole be higher or more restrictive than the general incidence of duties and regulations of commerce applicable in the constituent territories prior to the formation of such union...'. In cases of FTAs, Article XXIV: 5(b) makes the same requirement for the trade policy of each of the countries which are party to such an agreement.

According to the 1994 Understanding tariffs and duties evaluation should be based on an overall assessment of weighted average tariff rates and of customs union duties collected. This calculation is done by the WTO Secretariat based on import statistics for a previous representative period on a tariff line basis using the methodology used to compute the tariff offers in the Uruguay Round negotiations. It is critically important that the duties and charges taken into consideration should be applied rates of duty. Individual examination for non-tariff measures should be undertaken to assess whether their overall trade restrictiveness has increased or decreased.

\subsubsection{Analysis of the meaning of 'Duties and Other Regulations of Commerce? ${ }^{88}$}

36 If the transparency mechanism is strictly complied with the whole plan to establish an FTA (2008) or customs union (2010) should have been notified to the WTO as part of the subsequent notification.

37 Crawford, (note 23 above) p6

38 Here after ORCs 
There is a direct correlation between Article XXIV 5(a) $)^{39}, 5(\mathrm{~b})^{40}$ and 8(a) (ii) and subparagraph 8(a) (i) and 8(b) on the words 'duties and other regulation of commerce'. Sub-paragraph 5(a) and 8(a) (ii) form a coherent pair, both dealing with customs unions. According to sub-paragraph 8(a) (ii), the parties to a customs union must 'substantially' harmonise duties and other regulations of commerce applied to the trade of countries that are not part of the RTA, whether or not they are WTO Members. Sub-paragraph 5(a) requires that the newly harmonised ORCs plus any remaining un-harmonised ORCs applied in respect of trade with WTO Members that are not party to the RTA be no more restrictive than the ORCs previously applied in respect of such trade.

Examples of the regulation of commerce that could potentially constitute ORCs, include border measures ${ }^{41}$ regulating either the import of goods from third countries or the export of goods to third countries or the export of goods to third countries, and marketplace measures that may be applicable solely to the goods of third countries, to the goods of both third countries and RTA parties, or solely to the goods of RTA parties. During the Uruguay Round, one proposal was that the words 'duties and other regulations of commerce' should be interpreted to cover 'all border measures taken in connection with importation or exportation which have a differential impact on imported products as compared to domestic products. ${ }^{42}$ This proposal was rejected due to the inclusion of the word 'exportation', among other things. This might suggest that the negotiators did not agree that ORCs include export measures. A further difficulty with interpreting ORCs as including border measures on exports is

39 The duties and other regulations of commerce imposed at the institution of a customs union in respect to trade with WTO members not part to such union...shall not on the whole be higher or more restrictive than the general incidence of the duties and regulations of commerce applicable in the constituent territories prior to the formation of such union.

40 The duties and other regulations of commerce maintained in each of the constituent territories and applicable at the formation of an FTA to trade of WTO members not included in such area...shall not be higher or more restrictive than the corresponding duties and other regulations of commerce existing in the same constituent territories prior to the formation of the FTA.

41 This relates to ORCs relevant to sub-paragraphs 5 (a) 5 (b) and 8(a) (ii) of Article XXIV, these measures being applied to external trade. Examples are custom duties and similar charges, import prohibitions, quantitative restrictions and administrative rules regulating importation. Administrative rules include rules of origin used to distinguish between imports of goods originating in an RTA party and those originating in a third country. Border measures that restrict exports from RTA parties to third countries are more problematic.

42 WTO Committee on Regional Trade Agreements, Systemic Issues Related to 'Other Regulations of Commerce': Background Note by Secretariat(Revision) WT/REG/W/17/Rev1(5 February 1998) para10 
that such measures are generally applied by RTA parties to their own goods when destined for third country markets and therefore cannot be described as being applicable or applied to the trade of third countries within the meaning of Article XXIV:5 (b) and 8 (a) (ii).

With this provision GATT wanted to make sure that trade liberalisation continues even within the confines of an exception that created RTAs. This requirement concerns in principle the trade diversion effects to non members of the RTA. It has also been controversial. Preferential treatment provided to a partner country in an RTA leads to a reduction of demand for products from non-member countries even though external tariffs are not raised. Besides the compensation in the case of raising external tariff rates, the GATT fails to address such trade diversion and ignores the impacts such arrangements might have on outsiders even when they do not raise external tariffs.

McMillan ${ }^{43}$ has proposed one way to effectively avoid trade diversion. He suggests that any RTAs have to design external barriers, so that the volume of trade with the outside remains at least at the old level. With agreements leading to FTA or customs unions which inherently contain preferential market access provisions to member countries, this would be made possible by a corresponding reduction of external barriers. Like this proposal is the one raised by Bhagwati ${ }^{44}$ suggesting that the lowest pre-union tariff be adopted as a common external tariff. ${ }^{45}$ By eliminating the effects of trade diversion, this proposal would confine the effects of preferential agreements to trade creation, leading to the improvement of welfare for the countries involved.

Furthermore another merit of McMillan's proposal is that its implementation would provide the members of RTAs with an incentive to continue expanding membership

McMillan 'Does Regional Integration Foster Open Trade' 1-30

Bhagwati (note 13 above) p3

Adopting this rule would make countries with low tariffs less attractive partners for a $\mathrm{CU}$, and would thus lead to a reduction in the number of RIAs. However, high tariff countries will also be inclined to form CUs, strengthening the trade diversion effect. It will be interesting to follow what situation will arise in SADC where a proposed CU is due in 2010. Some SADC countries still have high tariffs while others have gone as low as zero. SACU tariffs, by virtue of its being a CU, are very low, while Mauritius has even fewer tariffs. If this rule were to be followed, the lowest tariffs that would have to be adopted for the SADC CU would be those of Mauritius. This is unlikely since some SADC members still rely heavily on tariffs for revenue. 
of the agreement until all of the important trading partners are included. If adopted by the WTO as a governing principle of regionalism, and the effect mentioned above comes to be realised, then this proposal has the potential to become an important instrument to widen the possibility for regionalism to become open regionalism, leading eventually to the strengthening of multilateralism.

However this proposition has its own shortcomings. There are both conceptual and practical challenges. In reality, in order to implement MacMillan's suggestion, countries should know, prior to the agreement, what kind of compensation they would have to pay. It is even more alarming to realise that there will inevitably be greater uncertainty about the extent of trade diversion likely to occur. Moreover, after the agreement comes into effect, separating the effects occurring because of tradediverting aspects of the agreement from other economic changes will be difficult, because a reduction in imports from the rest of the world may be influenced by other factors too. Additionally, RTAs could have dynamic effects that could lead to increased intra-RTA investment flows and to accelerating economic growth. This is highly likely to happen in a RTA like SADC, where there is one very strong and dominant economy, that of South Africa, that could increase intra-RTA investments. ${ }^{46}$ In the final analysis, therefore, outsiders could gain from increased imports induced by higher income generated by these dynamic effects, even though in the short term they might lose as a result of trade diversion.

\subsubsection{Fulfilling the requirement of less restrictive tariffs or policies in SADC}

In fulfilling this requirement SADC Member States may apply export duties, provided that third parties are not granted less favourable treatment than Member States. ${ }^{47}$ In addition, when dealing with intra-SADC trade, Member States shall adopt policies and implement measures which will lead to the elimination of all existing forms of non-tariff barriers. ${ }^{48}$ Accordingly Member States must also refrain from imposing any new non-tariff barriers. This is to be the general policy unless the Protocol provides otherwise. ${ }^{49}$ Even though this shows compliance on the part of SADC, the fulfilment

\footnotetext{
46 This aspect has already been emphasised in the discussion of the role of South Africa in chapter 6.

Article 5 of the SADC Protocol on Trade Ibid Article 6 of the SADC Protocol on Trade
} 
of this requirement is difficult to measure; non-tariff barriers are still very high in the region. ${ }^{50}$

The GATT also advocates the removal of qualitative restrictions: Member States shall not apply new qualitative restrictions. According to the Trade Protocol, existing restrictions on imports originating in Member States will instead be phased out. ${ }^{51}$ Any deviation from this understanding will otherwise have to be provided for by the SADC Protocol on Trade. ${ }^{52}$ The levying of quantitative restrictions on exports to other Member States is also prohibited unless it is provided for by the Protocol. An exception is, however, provided for Member States to take measures necessary to prevent the erosion of any prohibitions or restrictions which apply to exports outside the community as long as third parties are not granted less favourable treatment than Member States. ${ }^{53}$

Even the general exception clause does not deviate from the spirit of trade liberalisation in the Protocol on Trade. Further, even more importantly the exception does not seem to be in conflict with WTO regulations. The exception actually confirms compliance with the WTO obligations. The general exception reads as follows;

Subject to the requirement that such measures are not applied in a manner which would constitute a means of arbitrary or unjustifiable discrimination between Member States, or a disguised restriction on intra-SADC trade, nothing in Article 7 and 8 of this Protocol shall be construed as to prevent the adoption or enforcement of any measures by a Member State; ${ }^{54}$

a) necessary to secure compliance with laws and regulations which are consistent with the WTO;

b) necessary to protect intellectual property rights, or to prevent deceptive trade practices; or

c) necessary to ensure compliance with existing obligations under international agreements ${ }^{155}$

50 World Bank, Africa Trade Policy, November 2010 Available on: http://agritrade.cta.int/en/Keytopics/EPA-negotiations/Regional/SADC-configuration/News/SADC-trade-policy-Agriculturerelated-non-tariff-barriers-fragment-regional-markets Accessed 06/06/2011

Article 3 of the SADC Protocol on Trade

Article 7 of the SADC Protocol on Trade

Article 8 of the SADC Protocol on Trade

Ibid

Article 9 SADC Protocol on Trade (1996) This Article also contains all the remaining provisions $299 / 351$ 
In concluding this discussion on the requirement that new trade restrictions need to be 'not on the whole higher' than those that existed before the formation of the RTA, it is important to realise that there are shortcomings in the interpretation of this requirement. The proposed solutions also have their own shortcomings, therefore it is not easy to make recommendations or give a final decision about whether or not the provisions should really be reformed. If the GATT rule is maintained, it should be regarded as a minimum restriction on new RTAs. A reduction of external tariffs is desirable in global liberalisation, but in the current setting that is what the RTAs by themselves have to decide, either in a voluntary manner or as influenced by pressure from trading partners. Here, the potential of open regionalism to contribute to the strengthening of multilateralism can be identified; if there is a sufficient number of countries willing to exchange liberalisation, members of an RTA may be pressured to do the same, thus leaving regionalism open to outsiders. ${ }^{56}$

\subsection{Article XXIV: 8(b): The substantially all trade coverage requirement.}

According to this Article, duties and other restrictive regulations of commerce, except as otherwise permitted under GATT rules, should be eliminated on substantially all trade between the constituent territories. ${ }^{57}$

\subsubsection{Analysis of the elimination of barriers on the 'substantially all trade' requirement}

The meaning of 'substantially all trade' in Article XXIV:8 has given rise to much discussion over the years. ${ }^{58}$ To date, WTO Members have been unable to agree on the proportion of trade that amounts to 'substantially all trade', ${ }^{59}$ or how 'all trade' within an RTA is to be measured. ${ }^{60}$ According to the provisions of Article XXIV ${ }^{61}$, all

$56 \quad$ Park (note 9 above) 265.

57 Article 5:1 of GATS has similar language that an agreement should have substantial sectoral coverage, which is defined in terms of the number of sectors, the volume of trade affected and the modes of supply

58 Lockhart and Mitchell 'Regional Trade Agreements' 232

59 In view of the many difficulties surrounding the word 'substantially' New Zealand has suggested that the word should be removed from Article XXIV:8: WTO Committee on Regional Trade Agreements, Note on the Meeting of 16-18 and 20 February 1998,WT/REG/M/16(18 March) para 115

60 WTO Committee on Regional Trade Agreements, Coverage, Liberalisation Process and Transitional Provisions in Regional Trade Agreements: Background survey by the Secretariat, WT/REG/W/46(5 April 2002)

61 Sub paragraph 8 (a) refers to customs unions whose duties and other restrictive regulations of commerce (except where necessary, those permitted under Articles XI,XII,XIII.XIV,XX) are eliminated with respect to substantially all the trade between the constituent territories of the $300 / 351$ 
restrictive duties and regulations of commerce should be 'eliminated on substantially all trade' between the contracting parties to the regional trading agreement, and where the parties choose to adopt a common external tariff and trade policy, such should be 'no more restrictive than the policies/tariffs of the individual states prior' to the formation of the trading block. ${ }^{62}$ The main objective of Article XXIV was to prevent RTAs from becoming obstacles to the development of multilateral trade, but rather to make them a stepping-stone towards open trade. According to Article XXIV paragraph 8, RTAs (be they free trade agreements or customs unions) should result in the elimination of duties and non-tariff barriers on 'substantially all the trade'. As will be shown in the next section, this provision has proved to be one of the most contentious and difficult to define.

\subsubsection{Fulfilling the 'Substantially all trade' requirement}

The elimination of tariffs on substantially all trade is a requirement that has openly been questioned. The question is 'what amounts to substantially all trade?' The requirement to liberalise 'substantially all trade' within an RTA has been criticised by many analysts. According to Bhagwati ${ }^{63}$

This notion needs clarification because it is not clearly defined how much 'all' is 'substantially' all. This ambiguity is likely to lead to loopholes, thereby contributing to exclusion in related agreements of sensitive sectors such as agriculture and steel. To avoid this kind of loophole, it is suggested that the notion be changed into a phrase that requires liberalisation of 'all the trade'. Setting a certain percentage, for instance $80 \%$ percent or $90 \%$ of liberalisation across all sectors can also be considered as alternative to the 'all the trade' requirements.

What this means is that there is a need to clarify and specify the 'substantially all trade' requirement. The two suggestions of reform discussed above will contribute to successfully mitigating the regionalist tendency of the current world economy, but they also entail shortcomings. The suggestions of Bhagwati, for instance, seem to be

union or at least with respect to substantially all the trade in products originating in such territories. For FTAs, the corresponding requirement is contained in Article XXIV:8 (b) referring to duties and other restrictive regulations of commerce (except where necessary, those permitted under Article XI, XII,XIII,XIV,XV and XX) are eliminated on substantially all the trade between the constituent territories in products originating in such territories.

62 Sub paragraph 8 (a) (i) See discussion in Kumar U (assisted by Blumberg L) Article XXIV of GATT and Regional Arrangements in Southern Africa (1995) at 3

63 Bagwati (note 13 above) 25. 
too ambitious and idealistic and it is also uncertain that a total elimination of trade restrictions will increase overall welfare. ${ }^{64}$ In regions like SADC and many other African RTAs where intra-regional trade is significantly low, the removal of tariffs would not result in the increase of welfare. If adopted by the WTO, Bhagwati's suggestion could also be expected to give rise to unfair treatment between the existing and new regionalism. On the other hand, it considers only the liberalisation of RTAs and includes insufficient consideration of deep integration, which is one of the main effects of regional economic integration.

\subsubsection{Selected WTO jurisprudence on the meaning of 'substantially all trade'}

Appellate body panels have been called to interpret this term in dispute settlement. Up to now no panel has provided a satisfactory and detailed interpretation. A few cases will be described here in showing this trend. In the Turkey-Textiles case;

the Appellate body's interpretation was that 'substantially all trade' is not the same as all trade but that 'it is something considerably more than merely some of trade'. ${ }^{6}$

This interpretation means that the relevant amount of trade falls somewhere between some and all trade among the RTA parties. In the case involving the US-Line Pipe, the United States submitted evidence that NAFTA eliminated 'duties on 97 percent of the Parties' tariff lines, representing more than 99 percent of trade among them in terms of volume'.66 In this case the Panel held that the United States had established a prima facie case that NAFTA met the definition of an FTA under Article XXIV:8(b) ${ }^{67}$ This decision was made after the review of the evidence given and without offering an opinion on the meaning of 'substantially all trade'. The Appellate Body took the view that it was not necessary to address it and declared it to be of no legal effect. ${ }^{68}$

64 Frankel Regional Trading Blocks 12. His analysis is convincingly illustrative in this respect. His econometric model generates more favourable welfare effects in the case of partial liberalisation than in the case of total liberalisation. Based on this result, he argues that a removal of $100 \%$ intra-block trade barriers may not need strict enforcement, although he recognises the danger of accepting partial liberalisation as a rule.

Panel report, US-Line Pipe, para 7.142

Ibid para 7.144.

Ibid paras 198-199. 
If the panels and Appellate Body are left to decide on this notion they are likely to develop a flexible test premised on dividing the term into two. Firstly 'substantial' will be taken to indicate that the elimination of internal restrictions must cover a very considerable proportion of the trade between the parties. Secondly, the phrase 'all trade' will be used in identifying the broad base against which internal liberalisation is to be measured. This will ultimately lead to the panels' reaching a conclusion based on the specific facts at issue, each case being decided on the facts at hand. This jurisprudence could lead to an interpretation of what amount to 'substantially all trade' in SADC.

\subsubsection{Application of the 'Substantially all Trade' (SAT) interpretation in SADC}

In trying to fulfill the requirements listed above, the SADC Trade Protocol has made provisions for the phased elimination of tariffs and non-tariff barriers. ${ }^{69}$ The Committee of Ministers responsible for trade matters has determined the process to be followed for the phased elimination of tariffs and non-tariff barriers by doing the following; ${ }^{70}$

a) prescribing an eight-year time frame for the elimination of barriers $;^{71}$

b) granting a period of grace to afford additional time to those Member States who are of the opinion that they may be or have been adversely affected by the removal of tariffs and non-tariff barriers; ${ }^{72}$

c) Recognising that different tariff lines may be applied within the agreed time frame for different products in the process of eliminating tariffs and non-tariff barriers. $^{73}$

In fulfilling this requirement, the 85 percent threshold for the elimination of tariffs and non-tariff barriers was considered sufficient by SADC. To liberalise 80 percent to 90

69 According to Article 3 of the SADC Trade Protocol, import duties on goods originating in Member States will be phased out gradually and eventually.

70 Article 3 of the SADC Trade Protocol (1996)

71 Having been initiated in the year 2000, this was accomplished in 2008 with the launch of the FTA.

72 In accordance with this provision SADC Member States like Angola and the DRC did not join the FTA at its launch; they sought additional time to adjust to the low tariffs since their economies depended heavily on tariffs for revenue.

73 Article 3 (e), SADC Protocol on Trade. A Trade Negotiating Forum was responsible for negotiating the process and method of eliminating barriers to trade and the criteria to be followed for listing products for special consideration. 
percent of total trade among member countries of an RTA may be in line with the welfare argument raised by Frankel, ${ }^{74}$ which established an econometric model generating favourable welfare effects through partial liberalisation rather than through a total liberalisation. Partial liberalisation is ideal for SADC, where the majority of the Member States still rely heavily on tariffs as a source of revenue. ${ }^{75}$ Evidence is shown of the extent to which BLNS ${ }^{76}$ countries are dependent on the income from the SACU Revenue Pool, which accounted for between 13\% (Botswana), 28\% (Namibia) and 51\% (Lesotho and Swaziland) of total government income in 2001. ${ }^{77}$ Stern $^{78}$ emphasises that;

Revenue losses can arise as a direct effect of adopting a different tariff structure and in particular as a result of agreeing to apply no import tariffs to intra-group trade.

Further problems are envisaged, in that trade volume in one sector is not the result of one single factor; trade impediments may also influence trade relations. Consequently, it will not be easy to identify the product lines for which tariffs should be eliminated to reach the specified percentage. Additionally, shifts in demand and supply may affect the trade flows differently, which would also make it quite impossible to reach the exact value of the 80 to 90 percent for all trade. This situation has manifested itself in SADC as illustrated hereunder.

The 85 percent duty-free threshold was the target SADC set before launching the FTA. ${ }^{79}$ The interpretation of this provision is open to criticism since there is no prescribed formula for reaching such a threshold. SADC managed to reach the 85 percent threshold only by working out an average calculation covering all Member States. There was no uniform reduction of tariffs within SADC and Member countries failed to implement targets. ${ }^{80}$ In fact the 85 percent was made possible only because the SACU Members who are also SADC Members had very low tariffs, reaching zero

\footnotetext{
74 Frankel (note 65 above) 16

Kirk and Stern ,The New Southern African Customs Union Agreement' 29-52

BLNS countries are Botswana, Lesotho, Namibia and Swaziland.

(WTO 2003b:7) Trade Policy Review. '. Doc. WT/TPR/G/114, Geneva.

Stern 'Evaluation of an Appropriate Model for SADC' 50

FTA Brochure 'Hand book on SADC FTA, Growth, Development and Wealth Creation'. Available on www.sadc.in/fta/index/browse/page/219 Accessed on: 20 August 2010, See also the SADC Regional Indicative Strategic Development Plan (RISDP).

80 Niyiragira 'SADC Countries Fail to Meet Customs Union', Comment by Paul Kruger, a Tralac Researcher at the Trade Law Centre for Southern Africa (Tralac). Available on: http://www.pambazuka.org/aumonitor/comments/2538/ Accessed 20 August 2010
} 
in many instances. Since the SACU is already a Customs Union with very low tariffs, its contribution to the 85 percent average was enormous. This brings into question the rationale behind the requirement for the elimination of tariffs. Is the purpose to increase trade within the trade agreement? Even though there are valid reasons for accepting an asymmetrical approach to tariff liberalisation, the elimination of tariffs should be implemented equally across the board, especially considering that SADC Member States other than South Africa have poor economies.

Since the 'substantially all trade requirement' is not clear and SADC has reached an exceptional level of tariff elimination, this requirement has been complied with. The term 'substantially' implies that not all trade has necessarily to be covered. It is therefore argued that there is sufficient flexibility for some of the trade to be left outside of the coverage of liberalisation. The parties would have discretion as to which part of their total trade to liberalise. ${ }^{81}$ How much trade can be left outside of the coverage, however, remains an unanswered question. Additionally, another question could be what criteria should be used in the selection of products that form part or do not form part of the 'substantially all trade' category. Some Member States argue that 'substantially all trade' should be represented by a quantitative benchmark such as the percentage of trade covered, and/or a percentage of the total number of tariff lines. It is also argued that a qualitative benchmark is necessary in addition to the quantitative one. A qualitative benchmark is generally defined as the absence of systematic exclusion of any major sectors such as agriculture or textile. The preamble of the Understanding on Article XXIV alludes to the importance of not excluding any sectors from liberalisation in order to maximise the benefits arising from RTAs. It notes that the positive contribution that RTAs can have through the expansion of world trade is increased if the elimination between the constituent territories of duties and other restrictive regulations of commerce extends to all trade, and is diminished if any sector of trade is excluded.

African countries probably have an interest in a qualitative benchmark for trade coverage. Sectors and products where tariff peaks or restrictions to preferences are most commonly found are those where African countries have a comparative

81 See WTO Committee on Regional Trade Agreements, Communication from Australia- Addendum WT/REG/W/22/Add.1(24 April 1998) 
advantage (textile, agricultural products). The EU's interpretation of the 'substantially all trade' requirement has traditionally been that liberalisation should extend to at least $90 \%$ of the existing trade between the members of an RTA. This $90 \%$ coverage can be split unevenly between RTA members in order to reflect development asymmetries.

A calculation of the liberalisation granted by SADC members as a whole within the context of the Trade Protocol can be obtained by aggregating the duty-free tariff lines granted by each SADC member. In this formula SACU is counted as one, because it has already achieved a Customs Union status. The technique used is a simple average based on the total number of tariff lines and the total number of lines liberalised. Using this approach, calculations show that the overall liberalisation by SADC members amounts to 40.8 percent of tariff lines liberalised on entry into force of the Agreement. By 2015, when the last Member State, Mozambique, fully liberalises, it is assumed that the figure will rise to 99.7 percent. In terms of trade value (based on average 2002-2004 import values), overall liberalisation by SADC members amounted to 36.3 percent on entry into force. It is anticipated that it will reach 90.9 percent by the end of the implementation period. ${ }^{82}$

There is no accepted formula to calculate substantially all trade in the WTO; hence SADC's formula is ungrounded. However, if one looks at the kind of products not covered by the 85 percent threshold, it becomes clear that the decision to exclude motor vehicles, motor vehicles parts, textiles and certain clothing materials points to the protection of such industries. As the only industrialised member within the region, South Africa is the Member which seeks to protect its motor vehicle manufacturing industry ${ }^{83}$ and its textile industry. The South African motor industry was one of South Africa's most heavily protected industries prior to the trade liberalisation programme that was launched in the $1990 \mathrm{~s}^{84}$ but the levels of protection have not decreased to acceptable levels yet. Critically what this means is that South Africa is not willing to liberalise sectors where it has a comparative advantage. In some sense this suggests the continued existence in SADC of protectionist tendencies that are against the very objective of trade liberalisation. All of the other sectors forming the

This statistical analysis has been provided by the WTO Factual Presentation.

See generally, Bell 'Content Protection'. 68-79

Flatters and Netshitomboni 'Trade and Poverty in South Africa'. 22 
85 percent threshold could also be in areas where other SADC Member States have comparative advantage. The argument now is that 'substantially all trade' should be as close to $100 \%$ as possible so that trade liberalisation benefits can be felt in the majority of the sectors and for all of the countries involved. The 'substantially all trade' requirement has been complicated by the interim EPA pact that gives several of the SADC countries different levels of liberalisation. For example, Botswana, Lesotho and Swaziland will liberalise $86 \%$ of trade by value and tariff lines by the start of 2010, while Mozambique will liberalise $80.5 \%$ of trade. ${ }^{85}$

In finalising the discussion on the debate on 'substantially all trade', the merits and shortcomings of the suggested interpretations give rise to constructive ambiguity. This prevents countries from applying selective and/or sectoral liberalisation in just a few areas. This effect is expected also to strengthen if the international organisation, which possesses the power to make rules and enforce them, has enough authority to judge on it. Therefore, it seems that the problem currently being experienced is not the ambiguity incorporated in the 'substantially all trade' requirement, but that there is yet to be found an appropriate governance system for regionalism to prevent the misuse of the existing rules. ${ }^{86}$ Furthermore even though the DSB of the WTO can always be used, Members have shied away from using it for a variety of reasons, not least the fact that virtually all WTO members are engaged in RTAs and any resulting jurisprudence may have negative effects on their own arrangements. This form of governance will be ideally relevant at both multilateral level (WTO) and regionally (SADC and any other RTA) RTAs will have to find a better formula for the interpretation of 'substantially all trade', an interpretation that balances trade liberalisation equally both within and outside the RTA.

\section{The prescribed transitional period}

Another unclear aspect of the WTO Article XXIV rules on RTAs pertains to the length of the transition period for interim agreements. Liberalisation within RTAs is commonly achieved by gradual tariff reduction. In such a circumstance, the interim agreement must include a plan or a schedule for the finalisation of the customs union

Kruger 'SADC EPA negotiations'. 8-9

That the Committee on Regional Trading Arrangement (CRTA) which had been established within the WTO can take up this task needs still to be proved. 
or Preferential Trade Area. As part of the Uruguay Round, WTO members agreed to the Understanding on the Interpretation of Article XXIV of the GATT 1994, which inter alia provides that a reasonable period of time shall be construed as not more than 10 years, without a full explanation of why a longer period of time is required in the interim agreement. The period between the entry into force of an RTA and complete liberalisation between its members is called an interim agreement. Paragraph 8(c) of Article XXIV states that:

Interim agreements should be implemented '[...] within a reasonable length of time'. The Understanding on the interpretation of Article XXIV, paragraph 3 specifies: 'the reasonable length of time [...] should exceed 10 years only in exceptional cases'. Furthermore, the same paragraph adds that such exceptional circumstances require '[...] a full explanation to the Council for Trade in Goods of the need for a longer period'.

\subsection{Compliance with transitional period in SADC}

SADC has complied with the implementation of a transitional period. SADC implemented the FTA after 8 years of phased tariff reduction, which is two years earlier than the specified limit. Notwithstanding the fact that a few members of SADC are not party to the FTA, its implementation in 8 years (from 2000 to 2008) means that those who have not implemented it had a grace period of two years and 2010 was watershed year for the fulfilment of this requirement. SADC can still seek to extend the transitional period by approaching the CTG. This should be done in line with the decision by Mozambique and Zimbabwe to have fully complied with the FTA by 2015 and 2014 respectively.

The current arrangements on RTAs thus leave some degree of flexibility for transition periods longer than 10 years. However, the absence of any agreed definition of 'exceptional cases' and 'full explanation' leaves a high degree of uncertainty, which could jeopardise the legal security conferred by this flexibility. In existing North-South RTAs, transition periods sometimes exceed 10 years. For example, the Tunisia Euro-med agreement allows Tunisia up to 12 years to 
liberalise ${ }^{87}$ and South Africa is granted the same timeline to finalise its opening. ${ }^{88}$ Egypt was granted 15 years to liberalise some products under its Euro-med agreements. ${ }^{89}$ Finally, in its agreement with Canada, Chile was given 19.5 years to achieve its liberalisation. ${ }^{90}$ Even though it was the members who granted themselves these long transition periods, the WTO neither endorsed nor prohibited the decision. This, therefore, remains a grey area.

\subsection{Transitional period in the context of Economic Partnership Agreements ${ }^{91}$}

SADC is one of the African, Pacific and Caribbean (ACP) countries/organisations that are in the process of concluding EPA agreements with the EU. The ACP-EU relationship was essentially a trade aid package that presented an innovation establishing a legal framework between a group of developing countries on the one hand and a group of developed countries on the other. ${ }^{92}$ The ACP-EU relationship has been in existence for just over twenty-five years and involves seventy-seven developing countries in all. Of these, forty-eight are African countries and thirty-nine are least developed countries. ${ }^{93}$ Under the ACP agreements the ACP countries had preferential market access in the form of duty-free entry or a duty that was

87 See generally Grethe, Nolte and Tangermann, "The Development and future of EU. See also Löfgren, H., El-Said, M. and Robinson, S. 'Trade Liberalisation and the Poor: A Dynamic RuralUrban General Equilibrium Analysis of Morocco', 2001 in Dessus, S.; Devlin, J. and Safadi, R. (eds.), 'Towards Arab and Euro-Med Regional Integration', 129 - 146.

88 Greenberg S 'Raw Deal'. 16-19

89 Pierluigi 'The European Neighborhood' 45-64 See also McQueen M 'The EU's Free trade Agreement with developing countries: A case of wishful thinking?' 1369-85

90 Kuwayama and Yusuke 'The Comprehensiveness of Chilean Free Trade Agreements (FTAs)' 2002, paper presented to the APEC Study Centre, Institute for Developing Economies, Japan External Trade Organisation (JETRO), for Project 'WTO Liberalisation and the FTA Framework', forthcoming. 2001 Chiba, Japan.

91 Hereafter ACP countries. They are comprised of countries (currently 79: 48 African, 16 Caribbean and 15 Pacific), created by the Georgetown Agreement in 1975. The group's main objectives are sustainable development and poverty reduction within its member states, as well as their greater integration into the world's economy. All of the member states except Cuba are signatories to the Cotonou Agreement with the EU. The current wave of EPA negotiations and conclusions of agreements is an attempt to replace the Cotonou Agreement that was ruled to be illegal under WTO rules because of its non-reciprocity. See the WTO Panel ruling in the European Economic Community-Import Regimes for Bananas (Case I, II and III OF 1993, 1994 and 1996 respectively.) International Centre for Trade and Sustainable Development (ICTSD) May 2000. The WTO seeks to restore confidence after the fiasco of Seattle: http://ictsd.org/downloads/passerelles/passerelles2-1.pdf accessed 30 June 2011

92 Gakumu 'ACP Lome IV Convention'.

93 Prior to the Cotonou Agreement, there were four successive conventions between the fifteen EU countries and the seventy-one countries in the ACP. These were Lome 1, concluded on 28 February 1975 for a period of five years, which was renewed by Lome II (1980-85), Lome III (1985-90) and Lome IV (1990-2000) 
substantially lower than the normal MFN rate applied to the goods originating in the beneficiary countries. ${ }^{94}$ EPAs are considered north to south RTAs and hence compliance with the WTO is required. An earlier discussion showed that EPAs came into being as a measure designed to make trade between ACP countries and the EU WTO compliant. The EPAs sought to replace the Cotonou trade waiver, ${ }^{95}$ which was not based on reciprocity since it gave the ACP preferential treatment for exports into the EU market but did not require the ACP countries to grant preferential treatment to the EU. ${ }^{96}$

It is very likely that ACP countries will need long transition periods in the EPA process. In fact, ACP countries in their submission on RTAs to the WTO have requested that periods of at least 18 years be allowed. A long transition period would be crucial for them in the context of EPAs and other future RTAs in order to that they should have enough time for their industries to adapt to radically increased competition, as well as to introduce necessary measures to compensate for heavy tariff revenue loss. Finally, long transition periods will also be necessary to enable African countries to achieve regional integration prior to opening their trade to the EU, e.g. SADC's Regional Indicative Strategic Development Plan (RISDP) and the African Economic Community's 2028 goals. The modalities for transition periods are also unclear. What legal regime should be applied during the transition agreement? Are interim agreements subjected to some of the obligations of Article XXIV (5) and (8) as discussed earlier? How much of the trade between the two parties should be liberalised during the transition period and what of the other restrictive regulations of commerce?

\section{Conclusion}

In finalising this discussion, it is important to note that the implementation of Article XXIV has not worked well in practice. In the 47-year history of the GATT, only one

\footnotetext{
94 Onguglo 'Developing countries and trade preferences' 109

95 Cotonou Agreement (valid until 2008) and one for the EU's transitional banana regime (valid until 2006) was a compromise reached involving conceding Latin American countries the right to challenge the new banana regime if their current levels of market access was undermined by the application of preferences for ACP countries. See Saurombe 'The context of Economic Partnership Agreements (EPAs) for SADC: Available alternative' in Kierkegaard (ed) Business and Law, Theory and Practice. June 2008 
working party determined that a regional trading arrangement had satisfied the provisions of Article XXIV; ${ }^{97}$ yet none were found to be incompatible with GATT Rules. To emphasise the challenges of Article XXIV, a former GATT Deputy Director General complained that of all the GATT Articles, this is one of the most abused, and those abuses are among the least noted. ${ }^{98}$

Additionally the Leutwiler Group 1985 report to the GATT Director General similarly noted that the exceptions and ambiguities which have thus far been permitted have seriously weakened the trade rules. They have set a dangerous precedent for further special deals, fragmentation of the trading system, and damage to the trade interests of non-participants. GATT rules on customs unions and free trade areas should be examined, redefined so as to avoid ambiguity, and more strictly applied. ${ }^{99}$ From this analysis it is clear that the GATT Article XXIV rules are very elastic and vague. WTO rules on RTAs have largely been futile for the reason that they can be interpreted in various ways. ${ }^{100}$

Further findings show that treaty obligations that are imposed by general and equivocal wordings and provide ample scope of interpretation are always likely to be less complied with by states than those obligations that are imposed by precise and unequivocal wording. ${ }^{101}$ Understanding why the GATT sanctioned the formation of RTAs and imposed so little discipline on their formation requires further examination that goes beyond the scope of this paper. If non-compliance with Article XXIV provisions is commonplace, then that could well signal that the treaty provisions themselves are defective to some extent. It is doubtful that the drafters of Article XXIV fully appreciated its long term challenges. Even though this problem has been well documented, the call for reform has been resisted simply because of the fear of compromising the already delicate relationship between regionalism and multilateralism. The WTO rules relating to RTAs should therefore be clarified if they

97 This was the 1993 customs union between the Czech and Slovak Republics, two countries that had been joined together as an independent state for the previous 75 years. See WTO World Trade Report 2007, Six Decades of Multilateral Cooperation: What Have We Learnt? (Geneva, WTO2007) 306.

98 Chase, "Multilateralism Compromised" 63.

99 WTO, 1995:63, See also, Sutherland, P et al 'The Future of the WTO: Addressing Institutional Challenges in the New Millennium' Report by the Consultative Board to the Director General. www.wto.org (The Sutherland Report 2005)

100 McMillan (note 44 above) 1-30.1.

101 Chayes The New Sovereignty chapter 1 
are to be implemented to a greater degree. In particular the meaning of the phrases 'other regulation of commerce' and 'substantially all trade' require clarification. The negotiations for reforming Article XXIV at the WTO are going nowhere, but no matter how difficult they are, the reforms are necessary if the WTO is to remain a rulesbased system with real authority and if non-discriminatory free trade is not to be suppressed by a myriad of RTAs that do not conform to its rules. In these circumstances it is hard to determine SADC compliance with the rules.

\section{BIBLIOGRAPHY}

Bell RT "Content Protection"

Bell RT "Content Protection in the Motor Vehicle Industry in the Presence of Joint Ventures" 1989 South Africa Journal of Economics Vol 57, Issue 2 6879

Bhagwati Regionalism and Multilateralism

Bhagwati 'Regionalism and Multilateralism: An Overview', in $\mathrm{J}$ de Melo and A. Panagariya (eds), New Dimensions in Regional Integration (New York: Cambridge University Press: 1993

Chase "Multilateralism compromised"

Chase $\mathrm{K}$ "Multilateralism compromised: the mysterious origins of GATT Article XXIV" 2006 World Trade Review 5 1-30 United Kingdom

Chayes A The New Sovereignty:

The New Sovereignty Compliance with international Regulatory Agreements (Cambridge, MA, Harvard University Press 1995) chapter 1 
Crawford "A New Transparency Mechanism"

Crawford J "A New Transparency Mechanism for Regional Trade Agreements" 2007.Singapore Year Book of International Law and Contributors 133-140

Cottier T and Foltea M "Constitutional Functions of the WTO"

Cottier T and Foltea M 'Constitutional Functions of the WTO and Regional Trade Agreements', in Bartels L and Ortino F (eds) Regional Trade Agreements and the WTO Legal Systems (Oxford, Oxford University Press 2006)p43.

Curzon Multilateral Commercial Diplomacy

Curzon G Multilateral Commercial Diplomacy: The General Agreement on Tariffs and Trade and its Impact on National Commercial Policies and Techniques, 1965 London: Michael Joseph

Dam The GATT: Law and International Economic Organisation

Dam KW The GATT: Law and International Economic Organisation (University of Chicago Press: Chicago:1970)

Devlin J and Safadi R (eds.), Towards Arab and Euro-Med Regional Integration.

Devlin $\mathrm{J}$ and Safadi R (eds.), Towards Arab and Euro-Med Regional Integration Development Centre of the Organisation for Economic CoOperation and Development Economic Research Forum for the Arab Countries, Iran And Turkey-The World Bank, Development Centre Seminars, Paris: 129 - 146

Flatters F and Netshitomboni N "Trade and Poverty in South Africa

Flatters F and Netshitomboni N "Trade and Poverty in South Africa: Motor Industry" 2006 Paper prepared for the University of Cape Town's Southern Africa Labour and Development Unit (SALDRU) 
Frankel J Regional Trading Blocks 12

Frankel J Regional Trading Blocks Institute of International Economics, 1997

Gakumu P "ACP Lome IV Convention

Gakumu P "ACP, Lome IV Convention, an Evaluation of the Trade

Chapter" Brussels1990 (ACP Publication)

Greenberg S "Raw Deal

Greenberg S "Raw Deal: South Africa - European Union Trade Pact.2000" Southern Africa Report, Vol. 15 No. 3 16-19

Grethe H, Nolte S and Tangermann, S "The Development and future of EU

Grethe $\mathrm{H}$, Nolte $\mathrm{S}$ and Tangermann, $\mathrm{S}$ "The Development and future of EU Agricultural Trade Preferences for North-African and Near-East Countries" 2005, Paper prepared for presentation at the 99th seminar of the EAAE (European Association of Agricultural Economists), The Future of Rural Europe in the Global Agro-Food System, 23-27 August 2005, Copenhagen

Haight FA "Customs Unions and Free Trade Areas"

Haight FA 'Customs Unions and Free Trade Areas GATT: A Reappraisal' 1972 Journal of World Trade Law, 6 (4): 1-35

Kirk R and Stern M "The New Southern African Customs Union Agreement"

Kirk R and Stern M "The New Southern African Customs Union Agreement" Africa Region Working Paper Series No. 57. 2003 Washington: World Bank

Kruger P 'SADC EPA negotiations

Kruger $P$ 'SADC EPA negotiations: the circle of trust' Trade negotiations Insights, 5.8. December/January 2007/8 8-9

Kumar U "Article XXIV"

Kumar U 'Article XXIV of GATT and regional arrangements in Southern Africa' (1995) 4 
Kuwayama and Yusuke

Kuwayama M and Yusuke K "The Comprehensiveness of Chilean Free Trade Agreements (FTAs)" 2002, paper presented to the APEC Study Centre, Institute for Developing Economies, Japan External Trade Organization (JETRO), for Project "WTO Liberalization and the FTA Framework", forthcoming. 2001 Chiba, Japan

Lockhart JSN and Mitchell AD "Regional Trade Agreements"

Lockhart JSN and Mitchell AD "Regional Trade Agreements under GATT 1994: An Exception and its Limits' in Mitchell AD 'Challenges and Prospects for the WTO" International Law and Policy. Cameron May 2005

Löfgren H El-Said M and Robinson S "Trade Liberalisation and the Poor:

Löfgren $\mathrm{H}$ El-Said $\mathrm{M}$ and Robinson $\mathrm{S}$ "Trade Liberalisation and the Poor $\mathrm{A}$ Dynamic Rural-Urban General Equilibrium Analysis of Morocco" 2001 in Dessus, $\mathrm{S}$.

McMillan $Y$ "Does Regional Integration Foster Open Trade" McMillan $Y$ "Does Regional Integration Foster Open Trade? Economic Theory and GATTs Article XXIV", in K Anderson and R. Blackhurst (eds), Regional Integration and the Global Trading System (New York 1993) 1-30.

Montalbano, Pierluigi "The European Neighbourhood

Montalbano, Pierluigi "The European Neighbourhood policy: towards a new EU-MED partnership?" 2006 EIU WP Law 21 2007: p. 45-64 See also McQueen M "The EU"s Free trade Agreement with developing countries: A case of wishful thinking? The World Economy 2002 Vol 25.Issue 9. 1369-85

Niyiragira Y "SADC Countries Fail to Meet Customs Union"

Niyiragira $Y$ "SADC Countries Fail to Meet Customs Union", Comment by Paul Kruger, a Tralac Researcher at the Trade Law Centre for Southern Africa (Tralac) 
Onguglo BF 'Developing countries and trade preferences

Onguglo BF 'Developing countries and trade preferences' in M Rodriguez, $\mathrm{P}$ Low and B. Kotschwar (eds) Trade Rules in the Making: Challenges in Regional and Multilateral negotiations OAS 1999109

Park H S "Regionalism"

Park H S "Regionalism, Open Regionalism and Article XXIV GATT: Conflicts and Harmony" 2002 in Regionalism and Global Regulation of International Trade. Snyder F(ed) Studies in European Law and Integration.

Saurombe A The Context of EPA for SADC

Saurombe A The Context of Economic Partnership Agreements (EPA) for SADC: Available alternatives. In Kierkegaard S.M. Business Law, theory and practice 2008 362-370

Stern M "Evaluation of an Appropriate Model for SADC

Stern M "Evaluation of an Appropriate Model for SADC CU: Options for Revenue Collection and Allocation". Report Commissioned by SADC Secretariat.2007 p50

Sutherland P "The Future of the WTO:

Sutherland P "The Future of the WTO: Addressing Institutional Challenges in the New Millennium" Report by the Consultative Board to the Director General. www.wto.org (The Sutherland Report 2005)

\section{Register of Cases}

Turkey- Restrictions on Imports of Textile and Clothing products. Appellate Body 1995- (WT/DS34/AB/R)

United States- Definitive Safeguard measures on imports on Circular Welded Carbon Quality Line Pipe from Korea (WT/DS202/R) 
Register of treaties, instruments and legislation

Consolidated Text of the Amended Text of the Treaty of the Southern Africa Development Community (SADC)

SADC Protocol on Trade (1996)

ACP-EC Partnership Agreement- Cotonou 2000 (revised in Luxembourg 2005)

WT/MIN(01)/DEC/1, adopted on 14 November 2001.Paragraph 47 of the Doha Ministerial Declaration

WTO WT/L/671 16 Dec 2006. 'early announcement'.

WT/REG176/N/1/Rev.1 Notification of SADC to WTO by Tanzanian Mission

WT/REG176/3 Terms of reference for the examination of the Protocol by Council for Trade in Goods

WT/REG/W/17/Rev1 WTO Committee on Regional Trade Agreements, Systemic Issues Related to 'Other Regulations of Commerce': Background Note by Secretariat (Revision) (5 February 1998) para10

WT/TPR/G/114.Trade Policy Review. (WTO 2003b:7) "Southern African Customs Union. Report by the Secretariat".

WT/REG/W/22/Add.1 WTO Committee on Regional Trade Agreements, Communication from Australia- Addendum (24 April 1998)

\section{Register of Internet resources}

Ministry of Finance Zimbabwe 2009 www.zimtreasury.org 
ZIMRA charging $85 \%$ import duty for used cars yet we don't manufacture any cars hence no local industry to protect. Available on: http://www.zimtreasury.org/talk-totendai-detail.cfm?News=247. Accessed on 06/ 05.2010

FTA Brochure 2008 www.sadc.in/fta/index/browse/page 'Hand book on SADC FTA, Growth, Development and Wealth Creation. Available on www.sadc.in/fta/index/browse/page/219 Accessed on: 20 August 2010, See also the SADC RISDP 